KESMAS, Vol.9, No.1, Maret 2015, pp. $79-89$

ISSN: 1978 - 0575

\title{
FAKTOR RISIKO DALAM PENGGUNAAN PESTISIDA TERHADAP KELUHAN KESEHATAN PADA PETANI DI KECAMATAN BERASTAGI KABUPATEN KARO 2014
}

\author{
Eka Lestari Mahyuni \\ Staf Departemen Keselamatan dan Kesehatan Kerja, Fakultas Kesehatan \\ Masyarakat,Universitas Sumatera Utara \\ Email : eka_mahyuni@ymail.com
}

\begin{abstract}
Background:Pesticide application was a serious problem showed from occupational safety and health aspect. This research purposed to analyze the risk factor in pesticide application at farmer in Kecamatan Berastagi Karo Regency.

Method:This research was used explanatory research with cross sectional design. Sample reach by purposive sampling technique from all population which has a spray farmer of pesticide. The data was collect by observation and direct interview. The variable in this research are how the risk of pesticide application based related with the health complain because using the pesticide. The data were analyzed by chi-square test.

Result: The result showed there was a significant relation between, pesticide types ( $\mathrm{p}$ value $=$ 0,021 ), work period ( $\mathrm{p}$ value $=0,002$ ) and frequencies of times to spray (hour/day) by $\mathrm{p}$ value $=$ 0,018 with health complained that feels by the pesticide spray farmers.spray facility that potential effect by direct contact was not association with thr health complained.Samely with spray frequencies. Spraying farmers in Brastagi has risk to be toxic from direct contact because they are not using the personal safety equipment in completely and uncorrect using of pesticide from saving process that near by their kitchen and affected by the sun rising, in mixing process where using their hand to mix the pesticide, not care to wind flows when they spray the pesticide, and uncorrect throw the residue of pesticides in their land.

Conclusion: there was a relationship between pesticide types, work period and frequencies of times to spray. There is no association between spray facility and spray frequencies. Recommendation to the regency goverment to promote and train the farmers the correct of pesticide using. Beside to do the health screening to prevent the pesticide toxicity.
\end{abstract}

Key word: pesticide, spraying pesticide farmers, pesticide application, pesticide toxicity

\begin{abstract}
Abstrak
Latar Belakang:Penggunaan pestisida merupakan permasalahan yang perlu diperhatikan terutama dalam aspek keselamatan dan kesehatan kerja. Penelitian ini bertujuan untuk menganalisis faktor-faktor risiko dalam penggunaan pestisida terhadap keluhan kesehatan pada petani di Kabupaten Karo.

Metode:Jenis penelitian ini adalah explanatory research dengan pendekatan cross sectional. Sampel diambil dengan teknik purposive sampling dari seluruh populasi penyemprot pestisida di Kecamatan Berastagi. Data dikumpulkan melalui observasi dan wawancara langsung. Variabel yang diteliti adalahrisiko penggunaan pestisida berdasarkan lama kerja, waktu kerja, jenis pestisida dan proses penggunaan pestisida yaitu pencampuran pestisida, penyemprotan pestisida, dan penyimpanan pestisida. Hasil yang diperoleh dianalisa dengan menggunakan uji Chi square.

Hasil:Hasil penelitian menunjukkan bahwa terdapat hubungan yang significant antara jenis pestisida yang digunakan ( $p$ value $=0,021$ ), lama kerja $(p$ value $=0,002$ ), dan frekuensi lama penyemprotan (jam/hari) dengan $p$ value $=0,018$ dengan keluhan kesehatan yang dirasakan petani penyemprot pestisida. Penggunaan alat semprot yang berpotensi terjadi kontak langsung dengan pestisida tidak memiliki hubungan yang significant dengan keluhan kesehatan yang dirasakan petani. Sama halnya dengan frekuensi penyemprotan juga tidak memiliki hubungan dengan keluhan kesehatan. Petani penyemprot pestisida di Kecamatan Berastagi berisiko mengalami keracunan pestisida melalui kontak langsung akibat tidak menggunakan pelindung
\end{abstract}


diri yang lengkap dan penggunaan pestisida yang tidak tepat yaitu mulai dari proses penyimpanan yang dekat dengan dapur dan terkena sinar matahari, proses pencampuran dimana masih ada petani yang mencampur pestisida di wadah dengan menggunakan tangan, proses penyemprotan yang tidak memperhatikan arah angin, hingga pembuangan wadah pestisida habis pakai yang sembarang di lahan perkebunan.

Kesimpulan:Terdapat hubungan antara jenis pestisida, lama kerja dan frekuensi lama penyemprotan. Tidak ada hubungan jenis alat penyemprot dan frekuensi penyemprotan. Disarankan agar petani diberi penyuluhan dan pelatihan untuk meningkatkan kesadaran dan kepatuhan dalam penggunaan pestisida yang aman dan tepat dan sesuai prosedur. Di samping itu perlu dilakukan pemeriksaan kesehatan untuk mencegah efek keracunan pestisida.

Kata Kunci: pestisida, petani penyemprot, proses penggunaan pestisida, keracunan pestisida

\section{Pendahuluan}

Pestisida memiliki peranan besar dalam meningkatkan produksi pertanian. Berdasarkan pengalaman di Amerika Latin dengan menggunakan pestisida dapat menaikkan produksi hingga $40 \%$ pada tanaman cokelat. Di Pakistan pestisida membantu peningkatan produksi tebu sebesar 33\%, dan berdasarkan catatan FAO penggunaan pestisida dapat menyelamatkan hasil $50 \%$ pada tanaman kapas. ${ }^{1}$

Banyak penelitian yang telah menunjukkan hubungan antara penggunaan pestisida dengan gangguan kesehatan yang diderita pekerja. Menurut WHO, keracunan pestisida baik yang disengaja maupun tidak disengaja merupakan masalah yang serius pada komunitas pertanian di Negara miskin dan berkembang. Diperkirakan sekitar 250.000 kematian terjadi karena keracunan pestisida setiap tahunnya. ${ }^{2}$

Selama ini penggunaan pestisida oleh petani bukan atas dasar keperluan secara indikatif, namun dilaksanakan secara "cover blanket system" artinya ada atau tidak hama tanaman, racun berbahaya ini terus disemprotkan ketanaman. Selain itu teknik penyemprotan yang kadang melawan arah angin, menyebabkan petani menghirup pestisida tanpa disadarinya. Perilaku penggunaan pestisida yang berlebihan seperti itu justru menyebabkan masalah baru yakni adanya residu pestisida pada produk pertanian dan pada akhirnya membahayakan petani dan masyarakat luas baik keselamatan maupun kesehatan kerjanya. ${ }^{3}$

Kabupaten Karo merupakan salah satu sentra pertanian bagi Sumatera Utara terutama tanaman hortikultura jenis sayur-sayuran dan buah-buahan. Pertanian merupakan mata pencaharian terbanyak di masyarakat Karo. Hasil pertanian dari kabupaten ini tidak hanya dipasarkan ke dalam negeri tetapi juga luar negeri. Kabupaten Karo terdiri dari 13 kecamatan dimana masing-masing kecamatan memiliki lahan pertanian yang cukup luas. Salah satunya adalah Kecamatan Berastagi.

Kecamatan Berastagi di Kabupaten Karo merupakan salah satu kecamatan yang mayoritas penduduknya bermata pencaharian sebagai petani. Dalam melakukan pekerjaannya untuk meningkatkan hasil pertaniannya para petani selalu menggunakan pestisida untuk mengurangi serangan hama ataupun serangga pada usaha pertaniannya.

Berdasarkan hasil survei pendahuluan masih banyak penggunaan pestisida oleh petani di Kecamatan Berastagi yang kurang tepat. Diantaranya penggunaan pestisida tidak sesuai dengan dosis dan takaran yang dianjurkan, mengaduk campuran pestisida dengan tangan. Petani juga mengaku sengaja melebihkan takaran pestisida yang digunakan agar lebih efektif membunuh hama tanaman. Pada saat penyemprotan petani tidak menggunakan alat pelindung diri yang lengkap bahkan beberapa diantaranya melakukan penyemprotan sambil merokok bahkan tidak memperhatikan arah angin. Penyemprotan sering dilakukan pada pagi hari dan dilanjutkan dengan menyiangi tanaman sehingga petani seringkali tidak langsung mandi setelah melakukan penyemprotan. Namun biasanya petani hanya mencuci tangan kemudian 
beristirahat sebentar sambil merokok di sekitar lahan pertanian. Petani biasanya mandi pada sore hari setelah selesai melakukan pekerjaan di ladang mereka.

Menurut hasil wawancara dengan petani, beberapa petani mengaku sering merasakan gatal di kulit, pusing, dan mual setelah melakukan penyemprotan. Tetapi karena gejala itu tidak begitu mengganggu mereka biasanya tidak terlalu mempermasalahkannya.Berdasarkan uraian diatas maka tujuan dari penelitian ini adalah untuk menganalisis faktor risiko dalam penggunaan pestisida terhadap keluhan kesehatan yang dirasakan petani di Kecamatan Berastagi Kabupaten Karo.

\section{Metode Penelitian}

Jenis penelitian ini adalah explanatory research dengan desain cross sectional. Populasi pada penelitian ini adalah petani penyemprot pestisida di Kecamatan Berastagi Kabupaten Karo.Sampel diambil dengan teknik purposive sampling dengan kriteria keterbatasan jarak, waktu dan kesediaan petani penyemprot sebagai sampel penelitian.

Metode pengumpulan data dalam penelitian ini dilakukan melalui 2 cara yaitu:

a. Observasi dimana keseluruhan proses kerja petani dalam penggunaan pestisida akan diamati langsung mulai dari proses pencampuran pestisida hingga pasca penyemprotan pestisida.

b. Wawancara langsung untuk mengetahui hal-hal yang berkaitan dalam penggunaan pestisida yang dapat mendukung hasil observasi guna memperdalam hasil penelitian

Unit analisis dalam penelitian ini meliputi faktor risiko yang berhubungan dengan keluhan kesehatan yang dirasakan oleh petani. Teknik analisa data dilakukan dengan menggunakan uji chi-square untuk melihat hubungan antara faktor risiko dengan keluhan kesehatan yang dialami petani di Kecamatan Berastagi dalam penggunaan pestisida.

\section{Hasil Penelitian dan Pembahasan}

\section{A. Faktor Risiko berdasarkan Karakteristik Responden}

Penelitian ini dilaksanakan di Kecamatan Berastagi dimana petani penyemprot pestisida tersebar di lima desa yaitu Desa Sempajaya, Desa Raya, Desa Doulu, Desa Gurusinga, dan Desa Rumah Berastagi. Berdasarkan jenis kelamin dari petani yang dijadikan sampel terdiri dari 27 orang laki-laki dan 3 orang perempuan. Pendistribusian pekerjaan menyemprot pestisida ini sudah cukup baik berdasarkan kerentanan keterpajanan menurut jenis kelamin. Dikarenakan efek reproduksi lebih rentan dialami perempuan dibandingkan laki-laki, namun perlu diwaspadai kebiasaan merokok sambil menyemprot pestisida yang lebih cenderung dilakukan petani laki-laki lambat laun dapat meningkatkan risiko terjadinya keracunan dan penyakit.

Dari hasil penelitian masih terdapat 10 orang petani yang berada dalam rentang umur lanjut (>50 tahun). Keadaan ini menunjukkan risiko keracunan pestisida sangat berpotensi terjadi. Ditambah lagi pekerjaan sebagai penyemprot sudah dijalaninya selama berpuluh-puluh tahun.

\section{B. Faktor Risiko berdasarkan Jenis Pestisida yang Digunakan}

Dalam penggunaan pestisida perlu diperhatikan jenis pestisida yang digunakan. Dalam aturannya dianjurkan bahwa penggunaan pestisida pada satu tanaman adalah satu jenis saja. Namun dikarenakan banyak ragamnya dan organisme pengganggu tanaman yang sering menyerang tanaman, petani 
cenderung menggunakan beberapa jenis pestisida baik secara berkala ataupun sekaligus.

Pestisida yang paling banyak digunakan oleh petani penyemprot pestisida di Kecamatan Berastagi merupakan campuran dari 2 jenis bahkan 3 jenis pestisida yaitu campuran insektisida dan fungisida. Dari hasil wawancara, responden mengatakan semua jenis pestisida dapat dicampur karena semakin banyak jenis pestisidanya maka akan semakin ampuh membunuh hama tanaman. Hal ini bertentangan dengan salah satu dari lima asas prinsip penggunaan pestisida menurut Departemen Pertanian (2011) yaitu tepat jenis, dimana jenis pestisida yang digunakan harus sesuai dengan sasaran yang akan dibasmi.

Herbisida merupakan asam kuat, amin, ester atau fenol yang dapat menimbulkan iritasi pada kulit, bentuk merah pada kulit dan dermatitis.Dari penggunaan insektisida petani penyemprot pestisida dapat mengalami gangguan sistem saraf. Semua jenis insektisida baik organoklorin, organofosfat, carbamat dan piretroid adalah racun saraf. Hal ini dapat terjadi pada saraf perifer dan/atau pada sistem saraf pusat melaui mekanisme yang berbeda. ${ }^{7}$

Disamping insektisida dan herbisida petani juga menggunakan jenis fungisida. Fungisida merupakan bahan yang digunakan secara ekstensif sebelum dan sesudah panen, untuk mencegah terjadinya kerusakan pada tumbuhan akibat spora fungi, pada kondisi di bawah optimum terutama kelembaban dan temperatur. Apabila terpajan oleh fungisida melalui kulit maka akan terjadi iritasi dan dermatitis. Kebanyakan fungisida akan menyebabkan iritasi pada saluran pernafasan, selaput lendir, membrane mata dan hidung. Semua fungisida bersifat sitotoksik dan karena mutagenik, maka dapat menyebabkan mutasi, kanker dan teratogenik.

Beberapa keluhan yang dirasakan petani di Kecamatan Berastagi berdasarkan jenis pestisida yang digunakan antara lain kulit kemerahan dan gatal yang sifatnya hilang bila tidak kontak dengan pestisida dan muncul kembali bila kontak dengan pestisida, iritasi kulit dimana kulit kemerahan dan terasa panas dan sakit, pusing, sakit kepala, mual hingga sesak nafas. Hasil uji chi square diperoleh $p$ value sebesar 0,021 menunjukkan bahwa terdapat hubungan yang significant antara jpenggunaan jenis pestisida dengan keluhan kesehatan yang dirasakan petani penyemprot. Uraian ini dapat dilihat pada tabel 1 sebagai berikut:

Tabel 1. Hubungan jenis Pestisida dengan keluhan Petani Penyemprot pestisida di Kecamatan Berastagi

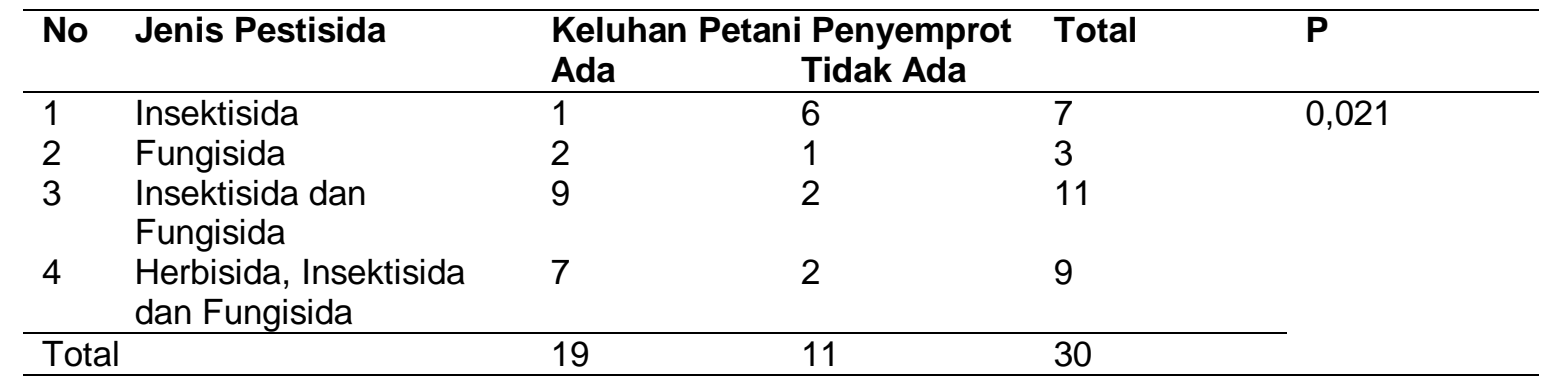

\section{Faktor Risiko berdasarkan Waktu Penyemprotan}

Penggunaan pestisida perlu diperhatikan secara serius mengingat bahaya dari pestisida yang dapat menyebabkan keracunan, penyakit, kanker bahkan kematian akibat keracunan ataupun terpapar pestisida. Tingkat pajanan terhadap pestisida tidak dirasakan langsung saat ini karena sifatnya yang kumulatif dan berpengaruh terhadap lama kerja yang dialami penyemprot pestisida sehingga 
pada akhirnya pajanan pestisida dapat menyebabkan kematian. Semakin lama petani penyemprot menggunakan pestisida maka diasumsikan semakin besar kemungkinan terjadinya keracunan bahan kimia pada petani penyemprot pestisida tersebut. Berdasarkan hasil uji chi square diperoleh $p$ value $=0,002$ menunjukkan bahwa terdapat hubungan yang significant bahwa lama kerja memberi peran dalam terjadinya kercunan. Hal ini dapat dilihat pada tabel berikut:

Tabel 2. Tabulasi silang lama kerja (tahun) dengan keluhan petani penyemprot.

\begin{tabular}{llllll}
\hline No & Lama Kerja & $\begin{array}{l}\text { Keluhan Petani } \\
\text { Penyemprot }\end{array}$ & Total & P \\
& Ada & Tidak Ada & & \\
\hline 1 & $<5$ tahun & 0 & 2 & 2 & 0,002 \\
2 & $5-10$ tahun & 1 & 6 & 7 & \\
3 & $11-15$ tahun & 9 & 2 & 11 & \\
4 & $>15$ tahun & 9 & 1 & 10 & \\
\hline \multicolumn{2}{l}{ Total } & 19 & 11 & 30 & \\
\hline
\end{tabular}

Fenomena ini dapat diasumsikan bahwa kemungkinan terjadi keracunan pada petani yang ditentukan dengan penurunan cholinesterase dalam darah sangatlah besar. Dengan lama kerja lebih dari 15 tahun kemungkinan terpapar pestisida sangat tinggi akibat lebih seringnya kontak dengan pestisida sehingga risiko keracunan pestisida semakin tinggi. Untuk itu sudah sebaiknya petani penyemprot pestisida perlu menjadi perhatian pemerintah ataupun Dinas Kesehatan setempat untuk melakukan pemeriksaan darah lebih lanjut guna melihat tingkat keracunan pestisida.

\section{Faktor Risiko Berdasarkan Alat penyemprot yang Digunakan}

Keterpaparan pestisida juga dapat terjadi melalui kontak langsung saat penggunaan pompa gendong dan mayoritas petani di Kecamatan Berastagi menggunakannya untuk menyemprot pestisida. Terkadang pada saat pemindahan pestisida yang telah dicampur ke pompa gendong kerap tertumpah dan mengenai langsung pestisida. Namun hasil uji chi square menunjukkan tidak ada hubungan yang significant ( $p$ value $=0.685$ ) antara keluhan dengan jenis alat penyemprot yang digunakan.

Dari aspek ergonomi, berat pompa gendong juga mempengaruhi kelelahan kerja akibat manual handling (mulai dari mengangkat, menopang beban, menurunkan dan memindahkan beban dari satu tempat ke tempat lainnya) yang dialami penyemprot. Dengan cara menyemprot yang sifatnya repetitif membuat punggung harus membawa beban kurang lebih $21 \mathrm{~kg}$ sambil berjalan menyisiri ladang yang cukup luas. Pekerjaan ini akan dapat menyebabkan stress pada kondisi fisik pekerja seperti pengerahan tenaga, sikap tubuh yang dipaksakan dan gerakan berulang yang dapat mengakibatkan terjadinya cedera, energi terbuang secara percuma dan waktu kerja yang tidak efisien.

\section{E. Faktor Risiko Berdasarkan Lama Penyemprotan}

Lama penyemprotan yang dilakukan di tiap lahan petani rata-rata 3 jam (43,3\%). Namun masih ada juga yang melakukan penyemprotan selama 6 jam per hari. Sedangkan frekuensi penyemprotan yang dilakukan 13 orang $(43,3 \%)$ terbanyak melakukan sebanyak 2 kali penyemprotan, 8 orang $(26,7 \%)$ frekuensi penyemprotan sebanyak 3 kali dan 2 orang $(6,7 \%)$ frekuensi penyemprotan 
sebanyak 7 kali. Hasil uji chi square menunjukkan bahwa frekuensi penyemprotan berdasarkan lama penyemprotan (jam/hari) memiliki hubungan dengan keluhan kesehatan dimana $p$ value $=0,018$. Namun frekuensi penyemprotan berdasarkan berapa kali melakukan penyemprotan tidak memiliki hubungan yang significant dengan keluhan yang dirasakan petani ( $p$ value $=0,406$ )

Tabel 3. Tabulasi Silang Frekuensi Lama Penyemprotan dengan Keluhan Petani Penyemprot di Kecamatan Berastagi

\begin{tabular}{llllll}
\hline No & $\begin{array}{l}\text { Frekuensi } \\
\text { Penyemprotan }\end{array}$ & $\begin{array}{l}\text { Keluhan Petani } \\
\text { Penyemprot } \\
\text { Ada }\end{array}$ & Tidak Ada & Total & P \\
\cline { 1 - 5 } 1 & 2 jam & 3 & 8 & 11 & 0,018 \\
2 & 3 jam & 11 & 2 & 13 & \\
3 & 4 jam & 3 & 1 & 4 & \\
4 & 6 jam & 2 & 0 & 2 & \\
\hline \multicolumn{2}{l}{ Total } & 19 & 11 & 30 & \\
\hline
\end{tabular}

Tabel 4. Tabulasi Silang Frekuensi Penyemprotan dengan Keluhan Petani Penyemprot di Kecamatan Berastagi

\begin{tabular}{llllll}
\hline No & $\begin{array}{l}\text { Frekuensi } \\
\text { Penyemprotan }\end{array}$ & $\begin{array}{l}\text { Keluhan Petani } \\
\text { Penyemprot } \\
\text { Ada }\end{array}$ & Tidak Ada & Total & $\mathbf{P}(\mathbf{C l}=\mathbf{0 , 0 5})$ \\
\cline { 1 - 5 } 1 & 1 kali & 3 & 4 & 7 & 0,406 \\
2 & 2 kali & 8 & 5 & 13 & \\
3 & 3 kali & 6 & 2 & 8 & \\
4 & 7 kali & 2 & 0 & 2 & \\
\hline \multicolumn{1}{l}{ Total } & 19 & 11 & 30 & \\
\hline
\end{tabular}

Pekerja yang bekerja dalam jangka waktu yang cukup lama dengan pestisida akan mengalami keracunan yang menahun, artinya makin lama bekerja maka akan semakin bertambah jumlah pestisida yang terabsorbsi dan mengakibatkan menurunnya aktivitas cholinesterase. Menurut Permenaker No. Per-03/Men1986 pasal 2 ayat 2a dinyatakan bahwa untuk menjaga efek yang tidak diinginkan maka dianjurkan supaya tidak melebihi 4 jam sehari dalam seminggu berturut-turut bila menggunakan pestisida. Sementara WHO menerapkan lama penyemprotan terpajan pestisida saat bekerja selama 5-6 jam per hari dan setiap minggu harus dilakukan pengujian kesehatan termasuk kadar cholinesterase darah. ${ }^{6}$

\section{F. Faktor Risiko Pada Proses Kerja Dalam Penggunaan Pestisida Pada Petani Penyemprot Pestisida}

Pekerja paling banyak terpapar pestisida pada saat melakukan penyemprotan, selain itu pada saat melakukan pencampuran, mengisi peralatan, membersihkan peralatan dan saat menangani kemasan kosong.

\section{Proses Penyimpanan Pestisida}

Penyimpanan pestisida merupakan salah satu faktor yang perlu diperhatikan dalam penggunaan pestisida. Hasil pengamatan yang dilakukan sarana penyimpanan pestisida sangatlah sederhana tertutama bagi petani yang menyimpan pestisida di kebun/ladang. Ada yang hanya meletakkan di atas papan-papan yang disusun namun ada juga yang menyimpan dalam gudang atau pondok sederhana yang tertutup. Petani yang menyimpan di rumah, pestisida diletak di belakang rumah dalam keadaan masih berlabel. 
Namun sangat dekat dengan dapur atau kamar mandi pemilik. Ada juga petani menyimpan pestisida di teras rumahnya dan posisinya sering terkena dengan sinar matahari.

Dari uraian diatas dapat dikatakan bahwa kesadaran petani mengenai bahaya pestisida masih rendah. Rendahnya kesadaran ini mungkin disebabkan rendahnya pengetahuan petani mengenai dampak pestisida pada tubuh. Cara penyimpanan yang terbuka ini memiliki risiko termakan atau terminum karena tidak jauh dari jangkauan anak-anak.

Menurut aturan penggunaan pestisida, pestisida yang disimpan dianjurkan untuk disimpan pada ruang tertutup dan terhindar dari sinar matahari untuk mengurangi faktor terjadinya penguapan akibat reaksi kimia dan fisika bahan kimia pestisida dengan udara. Selain itu, wadah pestisida yang sudah digunakan haruslah dibuang dan tidak tersebar dimana-mana. Sebab sisa-sisa pestisida yang ada di dalam kemasan pestisida yang telah habis pakai bisa saja mengalami reaksi dengan udara dan mencemari lingkungan bahkan membuat masyarakat terpapar dengan pestisida secara tidak langsung. Hal ini sesuai dengan pernyataan Sudarmo (1992) bahwa pestisida harus disimpan di tempat yang khusus dan dikunci agar jauh dari jangkauan anak-anak dan tidak terkena sinar matahari langsung. ${ }^{1}$

\section{Proses Pencampuran Pestisida}

Sebelum digunakan atau disemprotkan, petani penyemprot biasanya mencampur pestisida terlebih dahulu ke dalam wadah sebelum dimasukkan ke alat penyemprot. Pencampuran ini dilakukan untuk melarutkan atau mencampur pestisida sesuai dengan dosis dan takaran yang dianjurkan.

Hasil pengamatan menunjukkan bahwa petani di Kecamatan Berastagi melakukan proses pencampuran yang masih kurang tepat. Petani mengatakan bahwa pencampuran sebaiknya dilakukan di ruangan tertutup untuk menghindari adanya hembusan angin yang dapat menyebabkan terbangnya pestisida mengenai tubuh petani. Hal ini bertentangan dengan teori bahwa pencampuran pestisida sebaiknya dilakukan di tempat yang memiliki sirkulasi udara yang baik karena di tempat tertutup pestisida memiliki daya racun yang lebih tinggi sehingga dapat mengakibatkan keracunan melalui pernapasan.

Pada petani yang menggunakan mesin penyemprot, pestisida dicampur di dalam tong dan langsung diaduk oleh mesin penyemprot. Cara ini cukup aman karena petani hanya menuangkan jenis pestisida yang digunakan dan tidak ada kontak langsung yang cukup lama. Kekurangan yang ditemui pada proses ini adalah minimnya penggunaan alat pelindung diri. Dari 2 orang petani yang menggunakan mesin, tidak ada satupun menggunakan pelindung diri baik sarung tangan ataupun masker.

Berbeda dengan petani yang menggunakan pompa gendong sebagai media atau alat penyemprot pestisida. Proses pencampuran pestisida dilakukan pada ember kecil dan kemudian dituangkan ke pompa gendong. Pada saat mencampur pestisida tersebut, petani mengaduk pestisida menggunakan sendok kayu, ranting kayu, bahkan ada yang langsung menggunakan tangan. Alasan yang diutarakan pada petani rata-rata karena hal tersebut sudah biasa dan tidak ada pengaduk khusus pestisida sehingga petani menggunakan apa yang ada baik yang dibawa dari rumah ataupun yang ada disekitarnya.

Bila pencampuran dilakukan di tengah ladang dan tidak ada kayu atau ranting, maka pengadukan dilakukan dengan menggunakan tangan. Akibatnya sebagian petani sering mengeluh seperti pusing, tangan memerah, gatal dan pedih/sakit. Hal ini dialami pada saat kontak langsung mencampur pestisida. 
Bahkan ada petani yang mengaku kemerahan dan panas atau sakit seperti rasa pedih pada bagian yang terkena pestisida yang mana dirasakan pada tangan mereka dan akan menghilang paling cepat 3 hari dan selambatlambatnya 10 hari.

Cara mencampur pestisida ini juga menjadi perhatian dalam keselamatan kerja pada penggunaan pestisida. Dengan metode pencampuran yang seperti ini maka sangat besar kemungkinan terjadi kontak langsung dengan bahan kimia. Kontak langsung dalam pencampuran pestisida sangat tidak dianjurkan sebab kontak langsung dengan pestisida maka akan memicu terjadinya keracunan pestisida. Lambat laun bila kontak terus terjadi maka petani penyemprot pestisida dapat mengalami keluhan ataupun gejala-gejala seperti muntah-muntah, mual, pusing, iritasi dan beberapa gejala lain sesuai dengan tingkat keracunan yang dialami.

Kontak langsung dengan pestisida ini juga besar perannya berdasarkan sifat fisik pestisida yang digunakan. Pestisida dalam bentuk cair mungkin masih bisa dilakukan perlindungan dengan menggunakan media lain seperti kayu, sendok takar dan lainnya sehingga mampu menghindari kontak langsung dengan pestisida. Namun apabila pestisida yang digunakan memiliki bentuk fisik serbuk atau tepung, petani akan lebih sering melakukan kontak langsung dengan pestisida karena sifat pengerjaannya yang ditabur langsung pada tanaman. Rustia mengutip dalam Nurhayati (1997), menyebutkan bahwa pajanan yang terbesar dari penyemprot pestisida adalah melalui kulit adalah tangan. ${ }^{5}$

Hal yang perlu diperhatikan apabila terkena pestisida pada saat proses pencampuran ini adalah dengan langsung membersihkannya dengan air dan sabun ataupun arang aktif sesuai dengan sifat dan jenis bahan kimia yang terkena. Masih banyak petani yang membiarkan saja dirinya kontak langsung dengan pestisida. Petani merasa terciprat ataupun terkena pestisida sudah merupakan hal biasa sehingga mereka membiarkan saja tanpa membersihkan pestisida yang terkena pada tubuh.

Menurut Wudianto (2001), sewaktu mempersiapkan pestisida yang akan disemprotkan, pilihlah tempat yang sirkulasi udaranya lancar. ${ }^{8}$ Di tempat tertutup, pestisida yang berdaya racun tinggi terlebih yang mudah menguap, dapat mengakibatkan keracunan melalui pernapasan bahkan bisa mengakibatkan kebakaran. Selain itu jangan biarkan anak-anak berada disekitar lokasi ini. Buka tutup kemasan dengan hati-hati agar pestisida tidak berhamburan atau memercik mengenai bagian tubuh. Setelah itu tuang dalam gelas ukur, timbangan atau alat pengukur lain dalam drum atau ember khusus. Bukan wadah yang biasa untuk keperluan makan, minum dan mencuci. Tambahkan air lagi sesuai dosis dan konsentrasi yang dianjurkan. Untuk pencampuran pestisida janganlah dalam tangki penyemprot karena sudah dipastikan apakah pestisida dan air yang telah tercampur sempurna atau belum. Campuran yang kurang sempurna akan mengurangi keefektifannya. ${ }^{9}$

\section{Proses Penyemprotan Pestisida}

Penyemprotan pestisida merupakan proses dimana pestisida digunakan sesuai dengan fungsi dan kebutuhannya. Hal-hal yang perlu diperhatikan dalam penggunaan pestisida, di antaranya adalah keadaan angin, suhu udara, kelembaban dan curah hujan. Begitu juga dengan cara menyemprot pestisida. Diusahakan sebaiknya para petani menyemprot dengan cara yang dapat menghindari kontak langsung dengan pestisida yang disemprotkan. Sebab itu pestisida harus disemprotkan sesuai dengan tinggi tanaman. Semakin tinggi tanaman yang disemprot maka semakin besar risiko 
terpajan pestisida baik karena terpercik, terciprat, terbawa aliran udara, ataupun kontak langsung.

Hasil penelitian menunjukkan bahwa rata-rata penyemprot pestisida menyemprotkan pestisida pada tanaman yang rendah seperti daun prei, daun sop, kubis, kentang, tomat, wortel, strawberry dan cabe. Dari keseluruhan tanaman tersebut hanya kebun cabe yang cukup tinggi namun hanya setinggi paha petani. Metode atau cara menyemprot petani sebagian besar dengan arah ke bawah sesuai dengan tinggi tanaman. Penyemprotan biasanya dilakukan mulai pukul 06.00-11.00 pagi dilanjutkan pada sore hari mulai pukul 15.00-18.00 sore bila diperlukan. Petani berpendapat bahwa penyemprotan pada siang hari dapat menyebabkan berkurangnya kemampuan pestisida membunuh hama tanaman. Hal ini sudah benar karena Djojosumarto (2008) mengatakan penyemprotan yang terlalu pagi atau terlalu sore menyebabkan pestisida yang menempel pada bagian tanaman sulit kering sehingga terjadi keracunan tanaman, sedangkan penyemprotan pada siang hari menyebabkan bahan aktif pestisida menjadi terurai oleh sinar matahari sehingga daya bunuhnya menjadi berkurang. $^{8}$

Dari hasil pengamatan petani tidak menggunakan pakaian pelindung ataupun celemek plastik untuk menghindari bahaya tertumpah atau terpercik. Petani hanya menggunakan sepatu boot dan topi. Dengan tidak lengkapnya pemakaian pelindung diri kemungkinan risiko terkena pestisida cukup tinggi terutama pada petani yang menggunakan pompa gendong sebagai media penyemprot. Hal ini menunjukkan bahwa pengetahuan petani masihlah kurang tentang risiko bahaya pestisida sehingga bertindak dengan perilaku yang tidak aman. Sesuai dengan penelitian Marina br Karo (2013) bahwa sikap dan tindakan petani yang kurang mendukung adalah petai kurang setuju terhadap pemakaian APD, karena dianggap mengganggu dan kurang nyaman digunakan. Disamping itu mereka beranggapan bahwa APD tidak terlalu penting untuk digunakan, karena mereka menganggap selama menggunakan pestisida mereka baik-baik saja walaupun tanpa menggunakan APD. ${ }^{11}$

Untuk tanaman cabai dan tomat penyemprotan yang dianjurkan adalah setiap seminggu sekali namun petani menyemprot lebih sering yaitu setiap 2-3 hari sekali. Penggunaan pestisida yang begitu tinggi merupakan masalah serius karena akan menyebabkan tingginya residu pestisida pada tanaman. Selain itu penggunaan yang melebihi dosis yang ditentukan juga dapat menyebabkan hama menjadi resisten terhadap pestisida. ${ }^{3}$

Hasil penelitian menunjukkan petani menyemprot tanpa memperhatikan arah angin namun dengan arah bolak-balik sesuai dengan barisan tanaman. Sebenarnya petani mengetahui bahwa arah penyemprotan yang baik adalah sesuai dengan arah angin namun mereka menganggap menyemprot dengan memperhatikan arah angin lebih merepotkan dan memakan banyak waktu. Selain itu belum ditemukan efek langsung dari cara penyemprotan secara bolak-balik terhadap kesehatan sehingga petani tidak mengubah cara penyemprotannya. Namun dengan tidak mengikuti arah angin petani berisiko terpapar pestisida seperti terpercik atau terkena langsung ke bagian tubuh dan pakaian akibat hembusan angin yang berbalik ke arah tubuh penyemprot. Dan lebih berisiko apabila pestisida yang disemprotkan langsung mengenai organ mata yang tidak dilindungi dengan kaca mata pelindung.

Menurut Agung (2013) sebaiknya petani memakai alat pelinndung diri yang wajib dikenakan untuk meminimalkan masuknya pestisida lewat jalur pernapasan, inhalasi dan pencernaan, oleh karena itu pemakaian masker, topi, sarung tangan, baju lengan panjang dan celana panjang sangat 
dianjurkan untuk mengurangi risiko masuknya pestisida dalam tubuh yang dapat mempengaruhi tingkat cholinesterase. ${ }^{5}$

Rustia (2009) menerangkan bahwa petani penyemprot pestisida juga perlu melakukan tindakan seperti dibawah ini dalam penggunaan pestisida yaitu ${ }^{6}$ :

a. Harus mengikuti petunjuk yang tercantum dalam label. Jangan menyemprot pestisida selama 10 hari sebelum tanaman dipanen.

b. Apabila terjadi luka, tutuplah luka tersebut, karena pestisida dapat terserap melalui luka

c. Gunakan perlengkapan khusus, p akaian lengan panjang dan kaki, sarung tangan, sepatu kebun, kacamata, penutup hidung dan rambut, topeng muka.

d. Jangan mencium pestisida, karena pestisida sangat berbahaya apabila tercium

e. Sebaiknya pada waktu pengenceran atau pencampuran pestisida dilakukan di tempat terbuka. Gunakan selalu alat-alat yang bersih dan alat khusus.

f. Dalam mencampur pestisida sesuaikan dengan takaran yang dianjurkan. Jangan berlebih atau kurang

g. Tidak diperkenankan mencampur pestisida lebih dari satu macam, kecuali dianjurkan

h. Jangan menyemprot atau menabur pestisida pada waktu akan turun hujan, cuaca panas, angin kencang dan arah semprotan atau sebaran berlawanan arah angin dan makan/minum serta merokok. Bila tidak enak badan berhentilah bekerja dan istirahat secukupnya

i. Wadah bekas pestisida harus dirusak atau dibenamkan, dibakar supaya tidak digunakan oleh orang lain untuk tempat makanan maupun minuman

j. Pasanglah tanda peringatan di tempat yang baru diperlakukan dengan pestisida

k. Setelah bekerja dengan pestisida, semua peralatan harus dibersihkan, demikian pula pakaian-pakaian, dan mandilah dengan air sabun sebersih mungkin dan cuci tangan dengan sabun sebelum makan/minum dan merokok. Jangan mencemari kolam dengan pestisida.

Karena itu penggunaan alat pelindung diri yang lengkap sangatlah dianjurkan bagi penyemprot pestisida. Penggunaan APD oleh aplikator atau penyemprot pestisida akan menurunkan risiko terpajan pestisida, berdasarkan Permenkes No. 258/ MENKES/PER/III/1992 tentang Persyaratan Penggunaan Pestisida, untuk perlengkapan pelindung yang minimal harus digunakan berdasarkan jenis pekerjaan dan klasifikasi pestisida khusus penyemprotan di luar gedung dengan klasifikasi pestisida yaitu: ${ }^{10}$

1. Pestisidia yang sangat berbahaya sekali: sepatu boot, baju terusan lengan panjang dan celana lengan panjang, topi, pelindung muka, masker, dan sarung tangan.

2. Pestisida yang sangat berbahaya: sepatu kanvas, baju terusan lengan panjang dan celana lengan panjang, topi, masker.

3. Pestisida yang berbahaya; sepatu kanvas, baju terusan lengan panjang dan celana panjang, topi, masker.

4. Pestisida yang cukup berbahaya: sepatu kanvas, baju terusan lengan panjang dan celana panjang, topi.

\section{SIMPULANDAN SARAN}

\section{A. Simpulan}

KESMAS Vol. 9, No. 1, Maret 2015: $79-89$ 
Dari hasil penelitian yang telah dilakukan, maka dapat diambil kesimpulan sebagai berikut:

1. Faktor Risiko yang berhubungan dalam penggunaan pestisida dengan keluhan kesehatan yang dirasakan pada petani penyemprot di Kecamatan Berastagi adalah jenis pestisida, lama kerja, frekuensi lama penyemprotan (jam/hari)

2. Faktor risiko yang tidak berhubungan dalam penggunaan pestisida dengan keluhan kesehatan yang dirasakan petani penyemprot di Kecammatan Berastagi adalah jenis alat penyemprot dan frekuensi penyemprotan (hari/minggu)

3. Petani penyemprot pestisida di Kecamatan Berastagi berisiko mengalami keracunan pestisida melalui kontak langsung akibat tidak menggunakan pelindung diri yang lengkap dan penggunaan pestisida yang tidak tepat mulai dari proses penyimpanan, pencampuran, penyemprotan, hingga pembuangan wadah pestisida habis pakai.

\section{B. Saran}

1. Diharapkan pemerintahan Kabupaten Karo dapat memberikan penyuluhan secara berkesinambungan mengenai penggunaan pestisida yang aman dan tepat.

2. Meningkatkan kesadaran petani untuk melakukan perlindungan diri dari bahaya kimia melalui penggunaan alat pelindung diri dan kepatuhan terhadap prosedur penggunaan pestisida.

3. Dilakukannya pemeriksaan kesehatan khususnya enzim cholinesterase untuk mencegah keracunan pestisida dan meningkatkan kesehatan petani.

\section{DAFTAR PUSTAKA}

1. Sudarmo, S., Pestisida untuk Tanaman, Kanisius, Yogyakarta, 1992.

2. WHO, Prevention of Suicidal Behaviors: Feasibility Demonstration Project on Community Interventions for Safer Access to Pesticides, 2008. Available at http://www.who.int/mental_health/prevention/suicide/pesticides_safer_access.pdf, diakses tanggal 20 Maret 2013.

3. Departemen Kesehatan Republik Indonesia, Peraturan Perundang-Undangan yang Berkaitan dengan Pestisida, Direktorat Jenderal Pemberantasan Penyakit Menular dan Penyehatan Lingkungan Pemukiman, Jakarta, 2006.

4. Tarwaka, Ergonomi Industri, Dasar-dasar Pengetahuan ergonomi dan Aplikasi di Tempat Kerja, Harapan Press, Solo, 2010.

5. Agung Rosyid Budiawan, 2013, Faktor Risiko Cholinesterase Rendah pada petani Bawang Merah, Jurnal KEMAS 8 (2) (2013); 198-206

6. Rustia Hana, Pengaruh Pajanan Pestisida Pada Petani di Bandung, Tesis, FKM UI, 2009.

7. Soemirat, J., Toksikologi Lingkungan, Gadjah Mada University Press, Bandung, 2003.

8. Djojosumarto, P. Pestisida dan Aplikasinya, Agromedia Pustaka, Jakarta, 2008.

9. Wudianto, R., Petunjuk Penggunaan Pestisida, Penebar Swadaya, Jakarta, 2001.

10. Peraturan Menteri Kesehatan Republik Indonesia, Nomor 258 Tahun 1992, tentang Persyaratan Kesehatan PengelolaanPestisida, pdf, diacces Tanggal 23 Maret 2013.

11. Marina br Karo, Pengetahuan, Sikap dan Tindakan Petani Holtikultura dalam Penggunaan Pestisida di Desa Aji Mbelang Kecamatan Tiga Panah Lebih Baik dibandingkan Petani Holtikultura di Desa Deram Kecamatan Merdeka Kabupaten Karo Tahun 2011, Jurnal PANNMED, Volume 8, Nomor 1, hal.73-77, 2013 